\title{
MEMAKNAI KEMBALI ESKATOLOGI DAN SEMANGAT ETOS KERJA ISLAMI
}

\author{
Oleh: Nurwahidin \\ (Dosen Agama Islam, MKU - UI Jakarta)
}

\begin{abstract}
Abstrak
Iman kepada hari kiamat dan iman kepada qadha dan qadar Allah merupakan kunci dan dasar seseorang untuk membangun kerangka ajaran Islamnya. Iman ini juga merupakan bentuk dari aspek eskatologis yang akan mengiringi kehidupan manusia sebagai makhluk yang percaya dan yakin kepada apa yang diyakininya.

Ajaran tentang iman dalam Islam dikonsepkan dalam satu ilmu atau kajian yang disebut aqidah. Iman memberikan pengaruh yang sangat signifikan dalam sikap dan perilaku seseorang sehari-hari. Iman yang benar akan berpengaruh positif atas diri seseorang, sebaliknya iman yang salah akan berpengaruh negatif terhadap diri seseorang.

Terkait dengan etos kerja, orang yang beriman akan mendapatkan stabilitas jiwa yang muncul dari keyakinan terhadap semua takdir dan ketentuan Allah yang merupakan suatu sistem yang bijaksana. Orang yang imannya benar tidak akan cepat goyah dan putus asa ketika mengalami kesusahan, kekalahan, dan kegagalan dalam usahanya. Sebaliknya ia tidak akan sombong dan bangga diri yang berlebihan ketika apa yang diusahanya berhasil. Semuanya dihadapi dengan sikap dan perilaku iman yang benar yang membuatnya selalu bersyukur kepada Allah yang memberikan putusan tersebut.
\end{abstract}

\section{Pendahuluan}

Iman kepada hari akhir dan iman kepada qadha dan qadar Allah adalah salah satu pilar dalam iman Islam di samping lima pilar iman lainnya. Pilar ini sering disebut dengan rukun Iman. Iman kepada qadha dan qadar menyangkut ketentuan serta takdir yang telah ditetapkan oleh Allah Swt. sesuai dengan Sifat dan Asma-Nya. Iman ini merupakan bentuk dari aspek eskatologis yang akan mengiringi kehidupan manusia sebagai makhluk yang percaya dan yakin kepada apa yang diyakininya tersebut. Lalu bagaimana dan apa inti dari kepercayaan dan keyakinan terhadap hal yang susah untuk 
dirasionalisasi oleh akal pikiran manusia dan tampak takilmiah tersebut? Hal ini karena kepercayaan dan keyakinan yang terbentuk adalah suatu perihal yang utuh dan merupakan suatu ketundukan yang terbentuk di dalam diri suatu individu langsung kepada yang diyakininya tersebut melalui keyakinan dan kepercayaan secara transendental kepada Allah Swt.

Bagaimana mewujudkan suatu kepercayaan yang berkeyakinan dan menimbulkan efek yang membangun baik dalam berkeyakinan tersebut maupun dalam kehidupan sosial setiap individu manusia yang juga berkaitan dengan situasi dan kondisi dari makhluk-Nya dan jalanjalan apa yang dianjurkan untuk membentuk landasan bagi tujuan yang hendak dicapai dalam berkeyakinan. Dalam permasalahan ini terdapat kontradiksi dalam kepatuhan kepada Allah Swt. selaku Sang Pencipta dan yang disembah sepenuh jiwa dengan keharusan untuk berpikir atau memikirkan segala sesuatu yang menyangkut kehidupan manusia selaku makhluk yang mempunyai akal dan pikiran serta diamanatkan oleh Sang Pencipta untuk menghuni dan hidup berkembang di muka bumi. Tulisan ini akan membahas sekitar iman kepada hari akhir dan iman kepada qadha dan qadar Alllah, serta hubungannya dengan etos kerja.

\section{Pengertian Eskatologi}

Eskatologi adalah ajaran teologi mengenai akhir zaman seperti hari kiamat, kebangkitan segala manusia dan surga dan mengenai halhal akhir seperti kematian dan hari kiamat (Nasution, 1986). Dalam Islam terdapat konsep aqidah yang merupakan ajaran tentang keimanan terhadap keesaan Allah Swt. Aqidah ini merupakan keyakinan penuh yang dibenarkan oleh hati, diucapkan oleh lidah, dan diwujudkan oleh perbuatan. Inilah iman yang sebenarnya, dan kadar keimanan inilah yang memotifasi seseorang untuk tunduk dan patuh terhadap ajaran agamanya.

Tingkatan keimanan seseorang dapat dilihat melalui beberapa hal seperti berikut:

1. Komitmennya terhadap Islam seperti: iman, amal, ilmu, dakwah, sabar, dsb;

2. Kualitas sikap seperti: dengan kekuasaan, lisan, atau tulisan, hati, dsb.;

3. Motivasi prilaku, di antaranya: ikhlas atau ria; dan 
4. Kemampuan melaksanakan amal seperti: melaksanakan keseluruhan atau hanya sebagian, menyatakan iman tapi tak melaksanakan syariat (Depag RI, 2002).

Manusia diturunkan ke bumi bukan semata mata hidup dan berkembang secara bebas, namun manusia mempunyai suatu pertanggungjawaban terhadap Allah Swt. Allah akan menuntut pertanggungjawaban dari makhluk-Nya ini setelah munculnya hari kiamat sebagai batas dari kehidupan duniawi dan akhirat. Pada hari perhitungan setelah kiamat ini semua umat manusia yang pernah hidup akan dibangkitkan kembali dan semua perbuatan mereka sekecil dan sebesar apa pun dan sebaik serta seburuk apa pun akan mendapatkan ganjaran yang setimpal dari Allah Swt. Terkait dengan hal ini Allah Swt. berfirman, "... dan Allah melaknati (orang-orang munafik = pura-pura berimanan) dengan balasan bagi mereka azab yang kekal" (QS. al-Taubah (9): 68).

Setiap manusia yang diadili oleh pengadilan Allah ini akan bertanggung jawab langsung terhadap dirinya sendiri dan pertanyaan yang muncul akan berdasarkan pada keyakinan, tunduk dan patuh kepada Allah Swt. sesuai dengan ketetapan-Nya yang disampaikan melalui para nabi dan rasul yang diutus-Nya kepada manusia dan kaumnya. Keyakinan terhadap hari kiamat ini mengakibatkan manusia terbagi menjadi tiga kelompok:

1. Manusia yang takpercaya terhadap hari kiamat dan memandang kehidupan di dunia ini sebagai satu-satunya kehidupan yang ada;

2. Manusia yang menyangkal akan adanya hari kiamat, namun bergantung terhadap campur tangan atau bantuan pihak lain untuk mensucikan diri dan menebus dosa-dosanya; dan

3. Manusia yang yakin terhadap hari kiamat sebagamana yang ditentukan dalam ajaran Islam. Orang yang yakin akan hari kiamat dan yakin pula bahwa ialah yang akan mempertanggungjawabankan segala perbuatannya yang dilakukannya dan memperoleh pengawasan dalam dirinya setiap saat ia menyimpang dari jalan yang benar (Depag RI, 2002).

Jadi keyakinan kita akan adanya hari kiamat akan merupakan penurunan dari keyakinan kita terhadap Allah Swt. itu sendiri, yang di sini kita akan selalu diatur dan diawasi oleh-Nya atas apa yang kita pilih, pikir, dan lakukan di tempat yang dimiliki oleh-Nya. Manusia tidak dilepaskan begitu saja ke dunia ini sebagaimana binatang yang tidak bertanggung jawab. Manusia bertanggung jawab atas segala perbuatannya dan harus mempertanggungjawabkan perbuatannya 
kepada Allah. Setiap manusia akan menerima akibat dari segala perbuatan yang dilakukannya di dunia ini. Pengadilan atas diri manusia itu akan berlangsung terbuka dengan segala macam bukti untuk menjelaskan apa yang telah dilakukan oleh manusia di dunia ini, baik secara sembunyi-sembunyi maupun secara terang-terangan. (QS. al-Kahfi, (18): 49). Di dalam proses ini tidak seorang pun dapat memindahkan beban pertanggungjawabannya kepada orang lain. Setiap orang berdiri sendiri dalam mempertanggungjawabkan perbuatannya dan menantikan keputusan atas dirinya yang berada di dalam kekuasaan Allah semata.

Orang yang yakin akan adanya hari akhir dan yakin pula bahwa ia bertanggung jawab terhadap segala perbuatan yang dilakukannya, memperoleh pengawasan dalam dirinya setiap ia menyimpang dari jalan yang benar. Kesadaran akan adanya pengawasan di dalam dirinya itu membuat manusia menjadi takwa dan takut kepada Allah walaupun tidak ada orang lain yang menyaksikan perbuatannya. Ia akan melaksanakan kewajibannya dengan jujur dan tidak suka melakukan perbuatan-perbuatan terlarang.

\section{Makna Beriman Kepada Hari Akhir}

Beriman kepada hari akhir meliputi dua hal. Pertama, beriman kepada adanya kebangkitan dan dihimpunkannya manusia. Setelah kematian seluruh manusia, Allah kemudian menghidupkan kembali orang-orang mati dari kubur mereka serta dikembalikan setiap ruh kepada tubuhnya lalu bangkitlah umat manusia untuk menghadap kepada Tuhan mereka. Mereka dihimpunkan dan dikumpulkan di dalam suatu keadaan tanpa alas kaki, telanjang tanpa berpakaian dan belum berkhitan. Allah Swt. berfirman yang artinya: "Kemudian sesudah itu sesungguhnya kalian benar-benar akan mati, kemudian sesungguhnya kamu kalian akan dibangkitkan dari kuburmu dihari kiamat" (QS. al-Mu'minun (23): 15-16).

Kedua, beriman dengan hisab (perhitungan amal) dan mizan (timbangan amal). Allah menghitung amal setiap manusia berdasarkan amal yang mereka lakukan di dunia. Barang siapa termasuk ahli tauhid dan taat kepada Allah serta rasul-Nya ia akan mendapatkan perhitungan yang mudah dan ringan. Sebaliknya barang siapa termasuk ahli syirik dan maksiat akan mendapati hisab yang sulit dan berat.. Terkait dengan hisab Allah berfirman yang artinya: "Adapun orang yang diberi kitabnya dari sebelah kanan, maka dia akan dihitung amalnya dengan perhitungan yang mudah, dan dia akan 
kembali kepada kaumnya dengan gembira. Adapun orang-orang yang diberikan kitabnya dari belakang dia akan berteriak celakalah aku dan dia akan termasuk kedalam api yang menyala-nyala." (QS. alInsyiqaq (84): 7-12). Sedang terkait dengan mizan Allah Swt. berfirman yang artinya: "Kami akan memasang timbangan yang tepat/adil pada hari kiamat, maka tiadalah dirugikan seseorang sedikitpun. Dan jika amalan itu hanya sebesar biji sawi pun pasti kami mendatangkan (pahala)-Nya. Dan cukuplah kami sebagai pembuat perhitungan" (QS al-Anbiya' (21): 47).

\section{Keyakinan pada Qadha dan Qadar}

Qadha adalah ketentuan mengenai sesuatu atau ketetapan tentang sesuatu, sedangkan qadar adalah ukuran sesuatu menurut hukum tertentu. Allah berfirman "Allah tidak akan merubah suatu kaum sebelum kaum itu sendiri mengubah nasib mereka." (QS. alRa'du (13): 11). Ayat ini mengisyaratkan bahwa keputusan Allah itu digantungkan dengan usaha manusia. Oleh karena itu, apa yang disebut nasib tidak lain adalah berlakunya hukum sebab akibat dalam kehidupan manusia.

Menurut ayat al-Quran tersebut, manusia bebas memilih perbuatan yang akan dilakukannya. Ia bebas pula menentukan kepercayaan yang dianutnya dan dia akan memperoleh sesuatu, baik hukuman atau pahala, sesuai dengan pilihannya itu. Allah hanya menunjukkan jalan yang seharusnya diikuti oleh manusia. Manusia bebas memilih untuk menuruti atau tidak menuruti jalan itu. Allah tidak mengganggu pilihan manusia. Oleh karena itu, manusia harus mengerjakan penyelamatan dirinya dan penyelamatan ini hanya dapat terjadi dengan beriman dan beramal saleh.

Untuk memahami qadha dan qadar, manusia harus hidup dengan ikhtiar. Dalam kehidupan sehari-hari, takdir Ilahi berkaitan erat dengan usaha manusia. Usaha manusia harus optimal dan maksimal diiringi dengan doa dan tawakal. Tawakal yang dimaksud adalah tawakal dalam menyerahkan nasib dan kesudahan usaha kita kepada Allah, sementara kita terus berikhtiar serta yakin bahwa penentuan terakhir segala-galanya berada dalam kekuasaan Allah.

Dalam sehari-hari kita juga sering mendengar kata takdir. Kata takdir berasal dari kata qaddara yang berarti mengukur, memberi kadar atau ukuran. Semua makhluk dikenai takdir oleh Allah Swt., mereka tak dapat melampaui ketetapan itu dan Allah menuntun ke arah yang seharusnya (Ali, 2002). 
Perbedaan antara qadha dengan qadar terletak pada derajat, tingkat dan status. Hal ini terlihat pada status lebih dahulunya qadar dari pada qadha, qadar merupakan suatu ukuran dari apa yang ditetapkan Allah sedangkan qadha adalah hasil dari pada ukuran tersebut dan qadar adalah tahapan yang pada fenomenanya masih belum terpenuhi dan masih meninggalkan persoalan kemungkinan untuk berubah, karena belum mencapai penyelesaian, sedangkan qadha disebut juga sebagai tahapan akhir, dicapai ketika penyebab lengkap ditetapkan dan tak ada lagi tempat untuk pengharapan (Ali, 2002)

Bagaimana hubungan antara kehendak bebas manusia ini dengan ketentuan dan takdir Tuhan dalam pandangan para ahli masih saling berbeda pendapat. Di antaranya ada yang mengganggap bahwa kemungkinan munculnya kehendak bebas manusia yang mana telah ditentukan oleh Allah Swt. dalam qadar-Nya. Di sini dianggap bahwa semua kehendak bebas dari manusia yang akan dan telah mereka lakukan sebagai ketentuan yang telah ditetapkan serta ditentukan oleh Allah Swt.

Sebagai Muslim, kita haruslah percaya dan meyakini akan ketentuan dan takdir Allah. Jawaban yang dikemukakan para ahli mengenai fenomena yang terjadi di dunia ini terjadi di bawah batasan dan hambatan tertentu, tanpa menghiraukan tempat, waktu, dan kondisi. Dan dalam kerajaan alam tak ada makhluk yang takterbatas, takterukur, dan takbersyarat. Jadi semua makhluk di dunia itu terukur, terbatas, dan bersyarat dalam artian semua yang ada akan selalu memenuhi ketiga syarat di atas dan dapat dikatakan bahwa Allahlah yang mengakibatkan adanya semua eksistensi yang ada di dunia ini dan secara taklangsung batasan dan ukuran dari semua makhluk itu berada ditangan Allah Swt. dan atas kendali-Nya. Para ahli lainnya berpendapat bahwa kekuasaan Allah itu mutlak dan dapat berbuat apa saja, baik yang kelihatan adil maupun yang kelihatan takadil oleh manusia. Merujuk pada pendapat ini dapat dikatakan bahwa manusia hanya merupakan alat bagi Allah, dan tidak mempunyai kebebasan bagi diri manusia itu sendiri untuk menentukan nasibnya. Tentu saja hal ini bertentangan dengan isi QS. al-Ra'du ayat 13 di atas.

Kita juga mengenal hukum-hukum Allah yang mempunyai kadar dan ukuran tertentu. Jadi, sebelum meyakini akan hal eskatologi dan takdir ketetapan Allah maka seharusnya kita lebih dahulu meyakini akan keberadaan Allah Swt. itu sendiri berikut dengan hukum, sifat, dan segala hal menyangkut keesaan-Nya. Dengan demikian, dapat disimpulkan bahwa manusia memiliki kemampuan untuk bertindak 
atau memilih di antara takdir yang telah ditetapkan oleh Allah Swt. terhadap alam.

\section{Pengaruh Eskatologi dan Qadha dan Qadar terhadap Etos Kerja}

Kadar keimanan akan menjadi dasar berperilaku bagi setiap insan yang mengaku dirinya seorang Muslim. Dengan iman itulah seseoarang akan merasa diperhatikan oleh Allah Swt. dan keimanan ini takhanya menghindari dari perbuatan jahat, tetapi juga akan memberikan motivasi untuk berbuat kebaikan di muka bumi ini sebagai bekal untuk akhirat dan kesuksesan materil yang dirasakan di muka bumi. Di samping itu, kesimpangsiuran pendapat mengenai keharusan untuk langsung tunduk dan berkeyakinan terhadap ketentuan Allah dengan pertimbangan sulitnya untuk memecahkan persoalan qadha dan qadar ini mengakibatkan muncul anjuran agar tidak memikirkan perihal ini dan pemikiran rasional serta ilmiah dari manusia yang akan melandasi segala tindakan dari manusia serta anjuran Allah Swt. kepada umat manusia untuk menggunakan akal pikiran yang diberikan kepadanya. Karena itu, kita akan melihat dulu manfaat yang dapat diambil dari kepercayaan kita terhadap ketentuan Allah ini. Secarat teoritis di antara manfaat yang dapat dipetik adalah beriman terhadap ketentuan Allah menjadikan semakin lengkapnya tauhid seseorang, semakin besar kebahagiaan dan kesempurnaan jiwa orang itu pada kehidupan abadi. Artinya, seseorang percaya bahwa seluruh fenomena yang ada (eksistensi) bergantung pada kehendak Allah Swt. dan tak ada fenomena yang akan terjadi di luar rencana dan kehendak-Nya. Dengan demikian, dapat dimengerti bahwa keyakinan ini merupakan ajaran yang berangsur-angsur untuk memahami fakta dan bertujuan untuk menggabungkan pengetahuan manusia dan tauhid yang hendak dicapainya dalam hubungannya dengan Yang Mahaesa.

Sedangkan manfaat secara praktis dapat berupa suatu manfaat moral dan pendidikan, yaitu dengan meyakini qadha dan qadar, manusia melihat pada fenomena dunia dan peristiwa yang diatur oleh sistem bijaksana yang telah ditakdirkan oleh Allah Swt. Jika dilihat dari sudut pandang ini maka akan muncul aspek psikologis yang akan membangun jiwa si penganut keyakinan akan keimanan terhadap rukun iman dan memenuhi kewajiban serta memberikan kesenangan hati bagi Allah Swt.

Dalam menghadapi dunia kerja, dapat dipahami dari pemikiran di atas bahwa manusia akan mendapatkan stabilitas jiwa yang muncul 
dari keyakinan terhadap semua takdir dan ketentuan Allah yang merupakan suatu sistem yang bijaksana. Yang dimaksud di sini, manusia yang yakin dan percaya tersebut tak akan cepat goyah dan putus asa ketika mengalami kesusahan, kekalahan, dan peristiwa yang tak menyenangkan lainnya. Mereka juga tidak akan cepat terbuai dengan suatu peristiwa yang menyenangkan dalam hidup ini, sehingga ketidakstabilan yang ada akan dapat memunculkan sifat-sifat manusia yang takdisukai oleh Allah Swt. dan menimbulkan amarah murka darNya.

Kepercayaan terhadap hari akhir ini akan membimbing kita untuk berprilaku menurut apa yang diperintahkan oleh Allah Swt., dan keyakinan bahwa kita akan selalu diperhatikan oleh Allah yang Maha Mengetahui. Apa yang akan kita lakukan di muka bumi ini adalah berdasarkan pikiran dan pilihan bebas dari kita sendiri dan Allah memberikan pilihan ini adalah untuk menggunakan akal dan pikiran kita untuk patuh, tunduk dan meyakini serta melaksanakan semua perintah dan menjauhi larangan yang ditetapkan oleh Allah Swt. Dalam menjalankan hidup di sini, kita akan menemukan kesinambungan yang bersinergis antara kehidupan nyata yang kita alami dengan apa yang dikatakan Allah dalam al-Quran yang merupakan apa yang telah ditentukan dan direncanakan oleh-Nya.

Lalu bagaimana kaitannya dengan etos kerja manusia? Salah satu arti dari kata etos adalah semangat. Jadi, etos kerja artinya semangat bekerja. Barangsiapa yang etos kerjanya tinggi selalu bergairah dan bersemangat dalam menjalai kegiatan kerjanya. Mereka seolah-olah tidak mengenal lelah dan putus asa dalam menggeluti tugas-tugas yang menjadi tanggung jawabnya. Dalam jiwanya telah terpatri motto "Hari ini harus lebih baik dari hari kemarin". Motto ini berasal dari salah satu ajaran Islam yang sangat hebat tetapi kurang terlihat dari sebagian umat muslim masa kini. Siapa saja pada hari ini yang amalnya lebih baik dari kemarin maka tergolong orang beruntung, siapa yang amalnya sama saja dengan kemarin, tergolong orang yang merugi dan apabila amalnya lebih rendah dari kemarin maka ia tergolong orang celaka (al-Hadits).

Betapapun berat dan sulitnya kegiatan kerja yang menjadi tanggung jawabnya, ia selalu menggeluti tugasnya itu dengan ikhlas dan lapang dada, serta senantiasa merasa senang dan tenang dalam melaksanakan tugasnya. Dengan penuh kesadaran, tugas yang diembannya itu adalah salah satu ibadah bahkan setara dengan ibadah wajib. Apabila bekerja telah diyakini sebagai ibadah dan hal itu dilakukannya secara rutin dengan penuh kesadaran dan kecintaan, 
maka apabila orang itu tidak melakukannya karena suatu alasan, ia akan merasakan ada sesuatu yang hilang atau tidak lengkap dalam dirinya. Dalam hal ini Allah berfirman yang artinya, "Dan katakanlah:" Bekrjalah kamu, maka Allah dan Rasul-Nya serta orang-orang mukmin akan melihat pekerjaanmu itu, dan kamu akan dikembalikan kepada (Allah) Yang Mengetahui akan yang gaib dan yang nyata, lalu diberikan Nya kepada kamu apa yang telah kamu kerjakan." (QS. al-Taubah (9): 105).

Dalam realita, cakrawala pandang kaum Muslim modern atas dunia kehidupannya terbagi dalam dua kelompok. Pertama, kelompok yang lebih terfokus pada urusan 'pekerjaan'. Mereka sudah mencoba menampilkan kinerja yang profesional, tetapi motivasi kerjanya sangat rapuh, yakni hanya mencari uang semata. Akibatnya, dari motivasi yang kurang lurus tersebut, keinginannya untuk berderma di jalan Allah amat minim. Mereka merasa tidak pantas untuk mengeluarkan sedekah, infak, atau zakat karena toh yang bekerja adalah dirinya sendiri. Bukan orang lain. Ia merasa bahwa kekayaan yang ia raih bukanlah anugrah dari Allah, namun dari jerih payanya sendiri. Jadi, dalam mencari nafkah, mereka begitu punya semangat yang tinggi dan etos yang kuat. Akan tetapi untuk urusan ilmu atau belajar, mereka mencukupkan diri dengan pengetahuan yang yang sudah terakumulasi sebelumnya.

Kelompok kedua adalah mereka yang memfokuskan diri pada urusan keilmuan/'ibadah'. Kelompok ini amat gandrung pada urusan yang sifatnya 'intelektual-ritual', namun kurang bisa menampilkan sikap yang profesional dalam bekerja. Artinya, pekerjaan yang mereka tunaikan kualitasnya rendah, tidak tepat waktu, dan kurang cita rasa seni. Yang penting selesai, Bung! Adalah motto mereka. Dalam mengejar ilmu atau melakukan ibadah ritual. Mereka memang hebat, namun, dalam urusan pekerjaan, mereka tidak punya sikap yang sama (Mubarak, 2007).

Dewasa ini, ada pertentangan yang ekstrem antara ukhrawi dan duniawi. Memang, bila 'kerja' dibatasi maknanya pada matra ekonomi dan sosial saja, sekan-akan terdapat dikotomi antara profan-duniawi (pasar, kerja) dengan sakral-ukhrawi (masjid, belajar). Ideologi 'kaum pasar' semakin diperkuat dengan serbuan pandangan materialisme Barat yang amat memuja benda atau materi. Materilah yang menjadi standar apakah seseorang pantas atau tidak untuk dihormati, dihargai, dan diakrabi. Andil budaya media massa seperti televisi, majalah, koran, ataupun radio semakin memperteguh lagi akan pandangan dunia yang sebetulnya asing, dan tidak berakar pada nadi kehidupan 
kaum Muslim. Sedangkan 'kaum masjid' seolah-olah muncul di atas ketidakberdayaan dalam menghadapi kenyataan. Dan mereka berlindung di bawah istilah-istilah 'sabar', 'zuhud', 'doa', 'ziarah', dan sebagainya (Mubarak, 2007).

Sebenarnya, dikotomi antara 'kerja' dan 'belajar' tidak perlu terjadi. Karena, apabila kita menghayati ikrar kita secara mendalam pada proposisi "Iyyaka na'budu wa iyyaka nasta'in" dalam surat AlFatihah, maka dunia kaum Muslimin bernuasa ibadah yang sangat kental. Sehingga, jelas-jelas tidak ada pemisahan antara yang sakral dengan yang profan, yang duniawi dengan yang ukhrawi. Allah berfirman yang artinya: "Hai orang-orang yang beriman, penuhilah aqad-aqad (perjanjian) itu" (QS. al-Maidah (5) :1). Perjanjianperjanjian itu meliputi perjanjian-perjanjian antara Tuhan dan manusia, yakni kewajiban-kewajiban manusia kepada Tuhan; perjanjian antar manusia dan dirinya sendiri; dan perjanjian antara individu dan sesamanya. Dengan demikian, perjanjian yang dimaksud oleh ayat tersebut berkisar antara shalat ritual sehari-hari sampai menjual barang dagangan di bazar, dari sembah sujud sehingga kerja mencari penghidupan.

Berangkat dari pandangan yang tidak mendikotomikan antara yang sakral dengan yang profan, maka etos kerja umat Muslim selayaknya memerhatikan kualitas pekerjaannya. Artinya, dalam bekerja, karakteristik spiritual tetap terjaga dan terpelihara serta dilaksanakan dengan penuh tanggung jawab.

Tanggung jawab terhadap kerja berarti kesiapan untuk bertanggung jawab di hadapan Yang Mutlak, karena kerja adalah saksi bagi semua tindakan manusia. Dalam ushuluddin terdapat konsep ma'ad atau qiyamah yang bila diterjemahkan dalam bahasa keseharian akan sangat mendukung sekali terhadap profesionalisme dalam bekerja. Konsep ma'ad atau qiyamah di sini bukanlah suatu konsep yang hidup dan membumi..

Pernyataan yang mendalam terhadap prinsip ma'ad akan berimplikasi positif dan konstruksif terhadap perkembangan kepribadian umat Muslim. Setidaknya, dengan mengahayati prinsip tersebut, pemuda Muslim tidak mengenal pengangguran. Perspektif Islam yang padu, menolak membedakan antara yang sakral dengan yang profan, yang ukhrawi dan yang duniawi, yang religius dan yang sekuler akan berimplikasi bahwa sebagaimana kita mencoba khusyu dalam shalat, kita mencoba meng-khusyu-kan diri dalam bekerja. Dalam bahasa bisnisnya, berusaha bersikap lebih profesional. Lebih jauh lagi, sebagaimana ketakutan pada Allah dan tanggung jawab 
kepada-Nya dalan ekspresi shalat kita, maka demikian pula dalam halhal di luar shalat kita. Semuanya didasari bahwa Allah dan Rasul-Nya serta orang-orang mukmin akan melihat pekerjaan kita.

\section{Kesimpulan}

Untuk memahami keyakinan akan ada dan datangnya hari kiamat serta qadar dan qadha, manusia sebagai makhluk yang diciptakan oleh Allah Swt. haruslah hidup dengan berikhtiar atau berusaha dengan semangat yang tinggi dan optimis akan keberhasilan dari apa yang dilakukannya. Dalam kehidupan sehari hari, takdir atau ketentuan dari Ilahi ternyata sangat berkaitan erat dengan usaha manusia sehingga usaha manusia haruslah maksimal dan optimal serta selalu diiringi dengan doa dan tawakal. Setelah berusaha dengan sekuat tenaga, seseorang hendaknya berdo'a dan tabah menyerahkan nasib dan usahanya kepada Allah dan meyakini bahwa penentuan terakhir ada pada kekuasaan Allah Swt. Inilah yang merupakan makna dari ketentuan Allah dalam qadha dan qadar, yaitu proses usaha (ikhtiar), doa, dan tawakal kepada-Nya.

Kesadaran akan adanya pengawasan dari Yang Maha Kuasa dalam diri manusia akan mengakibatkan meningkatnya kadar keimanan, ketakwaan, dan rasa takut terhadap Allah Swt., sehingga dalam kehidupan sehari-hari manusia akan melaksanakan semua perintah dan meninggalkan semua larangan-Nya. Apabila ia khilaf maka ia akan langsung bertobat. Keyakinan kepada hari kiamat mendorong manusia untuk menyesuaikan diri dengan kerangka nilai abadi yang telah ditetapkan oleh Allah. Dan keyakinan ini pulalah yang membantu manusia untuk mengembangkan kepribadiannya secara sehat dan mantap sesuai dengan kemauan Allah Swt. Keyakinan yang dimaksud di atas akan memberikan manfaat, baik untuk kelangsungan hubungan dengan Sang Khalik maupun akan berguna untuk membangun kondisi psikologis dalam kehidupan sehari hari.

\section{Daftar Pustaka}

Ali, Mohammad Daud. (1988). Sistem Ekonomi Islam, Zakat dan Wakaf. Jakarta: UI Press. 
(2002). Pendidikan Agama Islam. Jakarta: PT Raja Grafindo Persada.

Al-Qur'an al-Karim.

Departemen Agama RI. (1984). Al-Qur'an dan Terjemahnya. Jakarta: Proyek Pengadaan Kitab Suci Al-Qur'an.

---------. (2002). Buku Teks Pendidikan Agama Islam pada Perguruan Tinggi Umum. Jakarta: Bulan Bintang.

Dewan Redaksi Ensiklopedi Islam. (1997). Ensiklopedi Isla., Jakarta: Ichtiar Baru van Hoeve.

Kaelany, HD. (2004). Islam Kasih dan damai bagi Alam. Jakarta: Restu Ilahi.

Mubarak, Zakky Sy. (2007). Menjadi Cendikiawan Muslim, Kuliah Islam di Perguruan Tinggi. Jakarta: Yayasan Ukhuwah Insaniyah.

Nasution, Harun. (1986). Akal dan Wahyu dalam Islam. Jakarta: UI Press.

Shihab, Quraish, M. (1999). Wawasan Al-Qur'an. Bandung: Mizan.

\section{Biodata Penulis}

Dr. Nurwahidin, M.Ag. adalah dosen tetap di UPT MKU Universitas Indonesia Jakarta. Studi S1 diselesaikannya dari Fakultas Bahasa dan Sastra Arab IKIP Bandung (sekarang: UPI Bandung) tahun 1989. Studi S2 diselesaikannya dari Jurusan Pengkajian Islam Program Pascasarjana UIN Syarif Hidayatullah Jakarta tahun 1996 dan studi S3 juga diselesaikan di lembaga yang sama tahun 2006. 